\section{Recent scientific and technical books}

\section{Physics}

FULLER, Everett G., and HAYWARD, Evans (edited by). Photonuclear Reactions. (Benchmark Papers in Nuclear Physics/2.) Pp.xviii + 426. ISBN-0-470 15142-0. (Stroudsburg, Pennsylvania: Dowden, Hutchinson and Ross, Inc., 1976. Distributed by Halsted Press, a Division of John Wiley and Sons, Inc., New York and London.) $\$ 38 ; £ 21$.

KILLEEN, John. Controlled Fusion. (Methods in Computational Physics: Advances in Research and Applications, Vol. 16.) Pp.xiii + 450. ISBN-0-12-460816-7. (New York and London: Academic Press, a Subsidiary of Harcourt Brace Jovanovich, Publishers, 1976.) $\$ 47 ; £ 27.25$ KESSLER, Joachim. Polarized Electrons (Texts and Monographs in Physics.)
Pp.ix+223. ISBN-3-540-07678-6. (Berlin and New York: Springer-Verlag, 1976.) DM $59.80 ; \$ 24.60$

LANDOLT-BÓRNSTEIN, Numerical Data and Functional Relationships in Science and Technology/Zahlenwerte und Funktionen aus Naturwissenschaften und Technik. New Series/Neue Serie. Editor-in-Chief: K. H. Hellwege. Group 2 Atomic and Molecular Physics/Atom- und Molekularphysik. Vol. 7: Structure Data of Free Polyatomic Molecules/Strukturdaten freier Mehratomiger Molekeln. By J. H. Callomon, E., Hirota, K. Kuchitsu, W. J. Lafferty, A. G. Maki and C. S. A. M. Hellwege. Pp.vii + 395. ISBN-3-540-07577-1. (Berlin and New York: Springererlag, 1976.) DM 360; $\$ 147.60$

LANDOLT-BORNSTEIN. Numerical Data and Functional Relationships in Science and Technology/Zahlenwerte und Funktionen aus Naturwissenschaften un Technil. New Series/Neue Serie. Editor-in-Chief: K. H. Hellwege. Group 2: Atomic and Molecular Physics/Atom- und Molekularphysik. Vol. 8 (Supplement to Volume 2/Ergänzung zu Band 2. Magnetic Properties of Coordination and Organometallic Transition Metal Compounds/Magnetische Eigenschaften der Koordinations- un Metallorganischen Verbindungen der Ubergangselemente, Ergänzungsband ISBN-3-540-07441-4. (Berlin and New York: Springer-Verlag, 1976.) DM 1100; $\$ 451$.

MËHRING, M. High Resolution NMR Spectroscopy in Solids. (NMR: Basic 540-07704-9. (Berlin and New York: Springer-Verlag, 1976.) DM 68; \$27.90.

\section{Chemistry}

FULLER, C. W. (edited by). Annual Report on Analytical Atomic Spectroscopy : Reviewing 1975, Vol. 5. Pp.viii + 267. ISBN-0-85186-757-X. (London: The Chemical Society, 1976.) $15 ; \$ 33.75$. cation. Vol. 2: Problems with Solutions. Translated by William Martin and Anthony J. Rackstraw. Pp.viii + 449. ISBN-0-471-01473-7. (London and New York: Wiley-
Interscience, John Wiley and Sons; Weinheim: Verlag Chemie, GmbH., 1976.) fis; $\$ 330$.

HEILBRONNER, Edgar, and BOCK, Hans. The HMO Model and its Application. Vol. 3: Tables of Hückel Molecular Orbitals. Translated by William Martin

John Wiley and Sons; Weinheim: Verlag Chemie, GmbH., 1976.) £9; $\$ 18$. KEITH, Lawrence H. (edited by). Identification and Anlaysis of Organic Pol-
lutants in Water. Pp. $x+718$. ISBN-0-250-40131-2. (Ann Arbor, Michigan: Ann lutants in Water. Pp.x+718. ISBN-0-250-40131-2. (Ann Arbor, Michigan: Ann
Arbor Science Publishers, Inc.; Chichester: John Wiley and Sons, Ltd., 1976.) $\$ 30.25 ; £ 17.90$

PEARSON, Ralph G. Symmetry Rules for Chemical Reactions: Orbital Topology and Elementary Processes. Pp.ix +548 . ISBN-0-471-01495-8. (New
London: Wiley-Interscience, John Wiley and Sons, 1976.) $\$ 31 ; £ 17.50$.

\section{Technology}

BLASCHKE, W. S., and McGILL, J. The Control of Industrial Processes by Digital Techniques: The Organization, Design and Construction of Digital Control Systems. Pp.viii + 185. ISBN-0-444-41493-2. (Amsterdam, Oxford
Elsevier Scientific Publishing Company, 1976.) Df. 77; \$29.75.

EVAN-IWANOWSKI, R. M. Resonance Oscillations in Mechanical Systems. Pp.xi+292. ISBN-0-444-41474-6. (Amsterdam, Oxford and New York: Elsevier Pcientific Publishing Company, 1976.) Dfl. 77; \$29.75.

Scientific Publishing Company, 1976.) Df. 77; \$29.75.
FLOWERS, T. H. Introduction to Exchange Systems. Pp.xvii + 326. ISBN-0471-01865-1. (London and New York: Wiley-Interscience, John Wiley and Sons, 1976.) $113 ; \$ 26$.

GOULARD, R. (edited by). Combustion Measurements: Modern Techniques and Instrumentation. (A Project Squid Workshop.) Pp.xii + 483. ISBN-0-12-2941 50-0. (New York and London: Academic Press, a Subsidiary of Harcourt Brace Jovanovich, $\$ 34.50 ; £ 21.05$.

JACOBSON, Kurt I., and JACOBSON, Ralph E. Imaging Systems: Mechanisms and Applications of Established and New Photosensitive Processes. Pp.319. (London and New York: The Focal Press, 1976.) $£ 11.95$ net.

MADDIN, Robert (editor-in-chief). Challenges and Opportunities in Materials Science and Engineering. (Anniversary volume of Materials Science and Engineering.) Pp.vi+ 264. (Lausanne: Elsevier Sequoia, S. A., 1976.)

MENDELSSOHN, K. (edited by). Proceedings of the Sixth International Cryogenic Engineering Conference, Grenoble, 11-14 May 1976. (ICEC, 6.) Pp.827.
ISBN-0-902852-58-2. (Guildford: IPC Science and Technology Press, Ltd., 1976.) f29. McDOUGALL, Angus. Fuel Cells. (Energy Alternatives Series.) Pp.xii +147 SBN-333-18408-4. (London and Basingstoke: The Macmillan Press, Ltd., 1976.) Hard cover $£ 7.95$; Paper cover $£ 2.95$.

PALMER, Andrew C. Structural Mechanics. (Oxford Engineering Science Texts.) Pp. $x+218$. ISBN-0-19-856128-8. (Oxford: Clarendon Press; London: Oxford University Press, 1976.) Paper $£ 3.50$ net; Boards $£ 7$ net.

ROBERTSON, J. Craig. A Guide to Radiation Protection. Pp.86. SBN-333 19278-8. (London and Basingstoke: The Macmillan Press, Ltd. 1976.) £4.95.
ROBERTSON, Angus (edited by). Video Yearbook 1977. Pp.286. ISBN-0-85642-

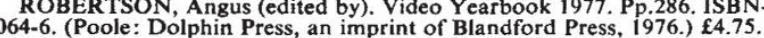

RUSSELL, Clifford S., and VAUGHAN, William J. Steel Production: Processes, Products, and Residuals. Pp.xx+328. ISBN-0-8018-1824-9. (Baltimore and London: The Johns Hopkins University Press, 1976. Published for Resources for the Future.) $£ 12.40$.

SZEKELY, Julian, EVANS, James W., and SOHN, Hong Yong. Gas-Solid Press, a Subsidiary of Harcourt Brace Jovanovich, Publishers, 1976.) $\$ 39.50 ; £ 24.10$

\section{Earth sciences}

GOLDBERG, Edward D. Strategies for Marine Pollution Monitoring. Pp.x + 310 . ISBN-0-471-31070-0. (New York and London: Wiley-Interscience, John Wiley and
Sons, 1976.) \$27.50; $£ 16.50$.

\section{Biological sciences}

ANDERSON, J. M., and MADFADYEN, A. (edited by). The Role of Terrestrial and Aquatic Organisms in Decomposition Processes. (The 17th Symposium of The (Oxford and London: Blackwell Scientific Publications, 1976.) £14.
BAKER, Joseph T, and MURPHY, Vreni. Handbook of Marine Science. Vol. 1: Compounds from Marine Organisms. Pp.228. ISBN-0-87819-388-X. (Cleveland, Ohio: CRC Press, Inc., 1976.) \$29.95.

BALTIMORE, David, HUANG, Alice $S$ and FOX, C. Fred (edited by) Anima Virology. (ICB-UCLA Symposia on Molecular and Cellular Biology, Vol. IV, 1976.) Pp.xi+824. ISBN-0-12077350-3. (New York and London: Academic Press. Subsidiary of Harcourt Brace Jovanovich, Publishers, 1976.) $\$ 29.50 ; £ 18$

BANKS, P., BARTLEY, W., and BIRT, L. M. The Biochemistry of the Tissues. Second edition. Pp.xv+493. ISBN-0-471-05471-2. (London and New York: John Wiley and Sons, 1976,) Cloth $£ 14.50 ; \$ 30$. Paper $£ 6.26 ; \$ 13.50$.

BROWN, Leslie. Eagles of the World. Pp.224. ISBN-0-7153-72696 (Newton Abbot and London: David and Charles, 1976.) £4.95

BROWN, Leslie. Birds of Prey: Their Biology and Ecology. Pp.256. ISBN-0 600-31306-9. (London and New York: Hamlyn Publishing Group, Ltd., 1976.) CA Prect or Bleomycin. (Progress in Biochemical Pharmacology, Vol. 11.) Pp.x+230. IS
(Basel, London and New York: S. Karger, 1976.) SFr./DM 127.

CHAPMAN, V. J. Coastal Vegetation. Second edition. (Pergamon International Library of Science, Technology, Engineering and Social Studies.) Pp.viii +292. $£ 8.75$; Flexicover $£ 4.75$.

\section{History of science} BRIEGER, Gert H. (edited by). Theory and Practice in American Medicine:
Historical Studies from the Journal of the History of Medicine and Allied Sciences. Pp.xv + 272. (New York: Science History Publications, a Division of Neale Watson Academic Publications, Inc., 1976.) Cloth \$12; Paper \$4.95.

COLLARD, Patrick. The Development of Microbiology. Pp.201. ISBN-0-521 COLLARD, Patrick. The Development of Microbiology. Pp.201. ISBN-0-
21177-8. (Cambridge and London: Cambridge University Press, 1976.) £6.50. COPER NICUS: On the Revolutions of the Heavenly Spheres. A New Translation from the Latin with an introduction and notes by A. M. Duncan. Pp.328. ISBN-0from the Latin with an introduction and notes by A. M. Duncan. Pp. 328. 1SBN-0. and Noble Books, a Division of Harper and Row, Publishers, 1976.) £12.50. GIFFORD, Jr., George E. (edited by). Physician Signers of the Declaration of
Independence. Pp.163. ISBN-0-88202-159-1. (New York: Science History Publi-

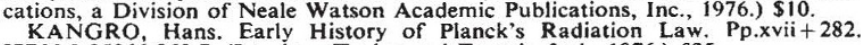
SBN-0-85066-063-7. (London: Taylor and Francis, Ltd., 1976.) £2s.

McCORMMACH, Russell (edited by). Historical Studies in the Physical Sciences. Seventh Annual Volume. Pp.xxxy+489. ISBN-0-691-08169-7. (Princeton, NJ: Princeton University Press, 1976.) $£ 19.80$.

\section{Anthropology}

BAKER, Paul T., and LITTLE, Michael A. (edited by). Man in the Andes: a Multidisciplinary Study of High-Altitude Quechua. (US/IBP Synthesis Series 1.)
Pp.xx +482 . ISBN-0-87933-228-X. (Stroudsburg, Pennsylvania: Dowden, Hutchinson and Ross, Inc., 1976. Distributed by Halsted Press, a Division of John Wiley and Sons, Inc., New York and London.) £18; \$30.

\section{Psychology}

BARBER, T. X. Pitfalls in Human Research: Ten Pivotal Points. (Pergamon General Psychology Series.) Pp.viit+117. ISBN-0-08-020935-1. (Oxford and New York: Pergamon Press, 1976.) \$6.95.

JUNG, C. G. Analytical Psychology: Its Theory and Practice. (The Tavistock Lectures.) Pp.xvi + 224. ISBN-0-7100-8414-5. (London and Henley: Routledge and Kegan Paul, Ltd., 1976.) Paperback 11.95

LIPSITT, Lewis P. (edited by). Developmental Psychobiology: The Significance of Infancy. Pp.x + 143. ISBN-0-470-15127-7. (Hillsdale, NJ: Lawrence Erlbaum Associated, Publishers, 1976. Distributed by Halsted Pre $\$ 12.65 ; £ 7.65$.
Wiley and Sons, New York and London.) $\$ 12$.

MEDLIN, Douglas L., ROBERTS, William A., and DAVIS, Roger T. (edited by). Processes of Animal Memory. Pp.xi + 267. ISBN-0-470-15189-7. (Hillsdale, NJ : Lawrence Erlbaum Associates, Publishers, 1976. Distributed by the Hals

NORMAN, Donald A. Memory and Attention: An Introduction to Human Information Processing. (Series in Psychology.) Second edition. Pp.xiii +262. ISBN-0-471-65136-2. (New York and London: John Wiley and Sons, Inc., 1976.) PORGES, Stephen W., and COLES, Michael G. H. (edited by). Psychophysiology. (Benchmark Papers in Animal Behavior/6.) Pp.xv+366. ISBN-0-470-15136-6. by Halsted Press, a Division of John Wiley and Sons, Inc., New York and London.) \$32; £17.75.

\section{Sociology}

BLACK, Donald. The Behavior of Law. Pp.xi+175. ISBN-0-12-102650-7. New York and London: Academic Press, a Subsidiary of Harcourt Brace Jovanovich, Publishers, 1976.) $\$ 12.50 ; £ 7.60$

CHIROT, Daniel. Social Change in a Peripheral Society: The Creation of a (New York and London: Academic Press, a Subsidiary of Harcourt Brace Jovanovich, Publishers, 1976.) $\$ 12.50 ; £ 7.25$.

KORNITZER, Margaret. Adoption. Pp.186. Fifth edition. ISBN-0-370-10059-X. (London: Putnam and Company, 1976.) Hardback £4.95; Paperback £3.50. McKEOWN, Thomas. The Modern Rise of Population. Pp.168.

ROSE Hdon: Edward Arnold (Publishers), Ltd., 1976.) Re Natural Sciences. (Critical Social Studies.) Pp.xxvi + 205. ISBN-0-333-21141-3. (London and Basingstoke: The Macmillan Press, Ltd., 1976.) Hard cover $£ 10$;

ROSE. Hilary, and ROSE, Steven (edited by). The Political Economy of Science: Ideology of/in the Natural Sciences. (Critical Social Studies.) Pp.xxvi+218. ISBN-0cover $£ 10$; Paper cover $£ 3.95$.

\section{Geography}

OEHSER, Paul H. (compiled and edited by). Research Reports. (Abstracts and reviews of research and exploration authorized under grants from the National Geographic Society during the year 1968.) Pp. $x+5$
ton, DC: National Geographic Society, 1976.) $\$ 5$.

\section{General}

BUSVINE, J. R. Insects, Hygiene and History. (London: The Athlone Press, University of London, 1976. Distributed by Tiptree Book Services, Ltd., Tiptree, FARSON, Daniel (compiled by). In Praise of Dogs. Pp.118. (London: George G. Harrap and Co., Ltd., 1976.) £3.95 net.

GOLDSTEIN-JACKSON, Kevin. Experiments With Everyday Objects. Pp.187. SBN-0-285-62245-5. (London: Souvenir Press, Ltd., 1976.) £3.

ROSZAK, Theodore. Unfinished Animal: The Aquarian Frontier and the Evolution of Consciousness. Pp.ix +271 . ISBN-0-571-11014-2. (London: Faber and
Faber, Ltd., 1976.) $£ 2.95$. 